\title{
Neuropathic Pain Dysregulates Gene Expression of the Forebrain Opioid and Dopamine Systems
}

\author{
Agnieszka Wawrzczak-Bargieła ${ }^{1}$ (D) - Barbara Ziółkowska ${ }^{1}$ (D) - Anna Piotrowska ${ }^{2}$ (D) Joanna Starnowska-Sokół ${ }^{2}$. \\ Ewelina Rojewska ${ }^{2}$ (D) $\cdot$ Joanna Mika ${ }^{2}$ (D) $\cdot$ Barbara Przewłocka $^{2}$ (D) $\cdot$ Ryszard Przewłocki $^{1}$ (D)
}

Received: 30 April 2019 /Revised: 17 January 2020 / Accepted: 22 January 2020 / Published online: 5 February 2020

(C) The Author(s) 2020

\begin{abstract}
Disturbances in the function of the mesostriatal dopamine system may contribute to the development and maintenance of chronic pain, including its sensory and emotional/cognitive aspects. In the present study, we assessed the influence of chronic constriction injury (CCI) of the sciatic nerve on the expression of genes coding for dopamine and opioid receptors as well as opioid propeptides in the mouse mesostriatal system, particularly in the nucleus accumbens. We demonstrated bilateral increases in mRNA levels of the dopamine D1 and D2 receptors (the latter accompanied by elevated protein level), opioid propeptides proenkephalin and prodynorphin, as well as delta and kappa (but not mu) opioid receptors in the nucleus accumbens at 7 to 14 days after CCI. These results show that CCI-induced neuropathic pain is accompanied by a major transcriptional dysregulation of molecules involved in dopaminergic and opioidergic signaling in the striatum/nucleus accumbens. Possible functional consequences of these changes include opposite effects of upregulated enkephalin/delta opioid receptor signaling vs. dynorphin/ kappa opioid receptor signaling, with the former most likely having an analgesic effect and the latter exacerbating pain and contributing to pain-related negative emotional states.
\end{abstract}

Keywords Chronic pain $\cdot$ Neuropathy $\cdot$ Mesostriatal system $\cdot$ Dopamine $\cdot$ Opioids $\cdot$ Nucleus accumbens

\section{Introduction}

Chronic pain is a common medical problem affecting nearly $20 \%$ of adults in Europe and North America (Breivik et al. 2006; Nahin 2015). Despite major progress in elucidating the mechanisms of nociception (Basbaum et al. 2009), many cases of chronic pain remain resistant to medical treatment, particularly those of the neuropathic type of pain, i.e., resulting from lesions or diseases of the somatosensory

$\overline{\text { Agnieszka Wawrzczak-Bargieła and Barbara Ziółkowska contributed }}$ equally to this work.

Ryszard Przewłocki

nfprzewl@ cyf-kr.edu.pl

1 Department of Molecular Neuropharmacology, Maj Institute of Pharmacology, Polish Academy of Sciences, 12 Smętna Street, 31-343 Kraków, Poland

2 Department of Pain Pharmacology, Maj Institute of Pharmacology, Polish Academy of Sciences, 12 Smętna Street, 31-343 Kraków, Poland nervous system (Turk 2001; Dickenson and Suzuki 2005; IASP Terminology 2017).

Chronic pain develops most often from acute pain states elicited by tissue or nerve damage and is most likely underlain by maladaptive plastic changes in the central nervous system produced in response to prolonged nociceptive stimulation. Whereas a large number of pain-related molecular alterations have been described in the spinal cord (Basbaum et al. 2009; Kuner 2010; Mika et al. 2013; Rojewska et al. 2014, 2018), there is also an emerging recognition of a vital role of supraspinal centers in the development and maintenance of chronic pain conditions. This applies not only to the classical components of the somatosensory pathway but also to limbic forebrain regions, which may contribute to the affective and cognitive aspects of pain perception, and exert descending control on nociception (Tracey and Mantyh 2007; Bushnell et al. 2013).

Among them, attention has focused on the mesostriatal dopamine system encompassing projections from the substantia nigra and ventral tegmental area to the dorsal and ventral striatum (the latter consisting chiefly of the nucleus accumbens, NAc) (Wood 2006; Baliki and Apkarian 2015; 
Taylor et al. 2016). Both animal and human studies have indicated that a portion of the dopamine neurons are activated by acute nociceptive stimuli (Brischoux et al. 2009; Budygin et al. 2012; Scott et al. 2006; Wood et al. 2007), that these dopaminergic responses are altered during chronic pain (see below), and that the mesostriatal system activity can influence the perception of pain. Thus, chronic pain tends to be exacerbated, and pain thresholds decreased by dopamine deficiency, such as that observed in humans with Parkinson's disease or in animals after 6-hydroxydopamine lesions of the mesostriatal pathway (Saadé et al. 1997; Wood 2006; Zambito Marsala et al. 2011; Sung et al. 2018). Dopaminomimetic drugs, in contrast, exerted analgesic effects in tonic/chronic pain when administered into the dorsal or ventral striatum, and these effects were mediated by the dopamine D2, but not D1 receptor (Altier and Stewart 1993, 1998; Ansah et al. 2007; Magnusson and Fisher 2000).

A considerable body of evidence now suggests that chronic pain is accompanied by an attenuation of dopaminergic neurotransmission in the mesostriatal pathway, as indicated by reductions of basal extracellular striatal dopamine levels, dopaminergic cell firing, and dopaminergic responses to both noxious and rewarding stimuli (Ozaki et al. 2002; Wood et al. 2007; Taylor et al. 2014; Wu et al. 2014; Martikainen et al. 2015; Ren et al. 2016). Given the essentially antinociceptive actions of mesostriatal dopamine, these changes might be regarded as potential contributing factors to the development and maintenance of chronic pain. Moreover, human studies demonstrated morphological changes and altered functional connectivity of neurons within the striatum/NAc of chronic pain patients (Geha et al. 2008; Baliki et al. 2010; Baliki and Apkarian 2015). Altogether, these data suggest that functional and structural changes take place in both presynaptic and postsynaptic parts of the mesostriatal dopamine pathway during prolonged pain that are likely to have clinical relevance. However, the molecular underpinnings of these changes remain poorly understood.

In addition to its major dopaminergic input, the striatum is also characterized by high expression of most molecules involved in endogenous opioid signaling, critical players in the modulation of pain. Thus, it expresses two precursors of opioid peptides, proenkephalin (PENK) and prodynorphin (PDYN), as well as all three opioid receptors, mu, delta, and kappa (MOP, DOP, and KOP receptors, respectively) (Gerfen 1992; Mansour et al. 1995). PENK-derived peptides act predominantly on MOP and DOP receptors, and PDYN-derived peptides act predominantly on KOP receptors (Chavkin et al. 1982; cf. Yaksh and Wallace 2011). Whereas the classic sites of analgesic actions of opioids are located in the brainstem and the spinal cord (cf. Yaksh and Wallace 2011; Gilron et al. 2015), endogenous opioids are released into the striatum in response to nociceptive stimulation (Lapeyre et al. 2001; Zubieta et al. 2002), and activation of MOP and DOP receptors in the NAc results in analgesia (Dill and Costa 1977; Schmidt et al. 2002). Moreover, Zubieta et al. (2001) demonstrated in humans that both sensory and affective measures of pain were negatively correlated with MOP receptor stimulation in the NAc by endogenous opioids. In contrast to MOP and DOP receptors, striatal KOP receptors appear to be associated with antianalgesic effects (Schmidt et al. 2002). The above findings imply that endogenous opioid signaling within the striatum/NAc is strongly involved in pain processing.

Therefore, the molecular alterations underlying chronic pain could include changes in striatal opioid peptide or receptor expression or activity in addition to altered expression of molecules directly implicated in dopaminergic neurotransmission. This idea is supported by functional observations, e.g., in humans suffering from fibromyalgia or trigeminal neuralgia, decreased availability of MOP receptor was reported in the NAc (Harris et al. 2007; DosSantos et al. 2012). In animal models, some behavioral and neurochemical measures of dopamine reward system hypofunction associated with chronic pain could be reversed by inhibiting actions of striatal dynorphins on the KOP receptor (Suzuki et al. 1999; Narita et al. 2005). Excessive activation of the dynorphin-KOP system is known to produce depression-like emotional disturbances, such as anhedonia, which are also common to chronic pain conditions in humans (Knoll and Carlezon Jr 2010; Borsook et al. 2016).

The above evidence strongly suggests that neural processes mediated by both dopamine and opioid systems within the striatum/NAc play important roles in the regulation of descending systems for nociception control as well as in the affective response to the experience of chronic pain. Knowledge of the molecular alterations occurring in these systems during chronic pain, and neuropathic pain in particular, which is scarce at present, seems crucial to understanding their likely contribution to the development and maintenance of neuropathic pain conditions. Thus, we undertook the present study with the aim of providing a comprehensive profile of gene expression changes that occur in the NAc and dorsal striatum in a mouse model of neuropathic pain, considering a set of genes relevant to dopaminergic and opioidergic signaling within these forebrain regions. We demonstrate that strikingly many of these genes are upregulated in the NAc as a result of painful neuropathy.

\section{Materials and Methods}

\section{Animals}

Adult male Albino-Swiss CD-1 mice (20-25 g; Charles River, Sulzfeld, Germany) were used in this study. Animals were housed in groups of six in cages with sawdust bedding under 
a standard $12 \mathrm{~h} / 12 \mathrm{~h}$ light/dark cycle (lights on at $06.00 \mathrm{a} . \mathrm{m}$.); food and water were available ad libitum. The experiments were carried out according to the ethical standards and recommendations of the International Association for the Study of Pain (Zimmermann 1983), the European directive no. 2010/63/UE, and Polish regulations. The experimental protocol was approved by the Local Bioethics Committee (Krakow, Poland, permission number 1214/2015).

\section{Chronic Constriction Injury and Animal Treatment}

Chronic constriction injury (CCI) to the sciatic nerve was performed under 1:1 10\% ketamine/2\% xylazine (i.p.) anesthesia using the procedure described by Bennett and Xie (1988). Briefly, an incision was made below the right hip bone, parallel to the sciatic nerve. The sciatic nerve was exposed, and three ligatures (4/0 silk) were tied loosely around the nerve distal to the sciatic notch with $1 \mathrm{~mm}$ spacing until a brief twitch in the respective hind limb was observed. According to our previous studies, such treatment results in neuropathic pain reflected by tactile and thermal hypersensitivity in the ipsilateral paw, which lasts for more than 3 weeks (Osikowicz et al. 2008; Mika et al. 2009). The study consisted of two experiments, one using the in situ hybridization (ISH) method and the other using quantitative reverse transcriptionreal-time PCR (qRT-PCR) and Western blot. The mice were sacrificed by cervical dislocation at 7 or 14 days after the operation for the ISH and qRT-PCR/Western blot analyses, respectively. Naive control groups were sacrificed simultaneously.

\section{Behavioral Tests}

Von Frey's Test Mechanical tactile hypersensitivity in CCI mice was measured on the 7th and 14th day after CCI using a series of von Frey filaments (Stoelting, Wood Dale, IL, USA), ranging from 0.6 to $6 \mathrm{~g}$ (Mika et al., 2015). Animals were placed in plastic cages with a wire-mesh floor, allowing them to move freely. They were allowed to acclimate to this environment for approximately 5 to $15 \mathrm{~min}$ prior to testing. The von Frey filaments were applied in ascending order to the midplantar surface of each hind paw through the mesh floor. Each probe was applied to the foot until it started to bend. The ipsilateral and contralateral paws in CCI mice (or both hind paws in naive mice) were tested 2 to 3 times and a mean value was calculated. The time interval between consecutive applications of filaments was at least $5 \mathrm{~s}$.

Cold Plate Test Sensitivity to noxious thermal stimuli was assessed on the 7th and 14th day after CCI using a Cold/Hot Plate Analgesia Meter from Ugo Basile (Gemonio VA, Italy). The latency was defined as the amount of time it took for the hind paw to begin to shake after the mouse was placed on a cold plate $\left(2{ }^{\circ} \mathrm{C}\right)$. In $\mathrm{CCI}$ mice, the injured paw reacted first in all cases. The ipsilateral paw reaction was noted first and then the contralateral paw response was awaited and noted. In naive mice, the reaction of any hind paw was noted. The cut-off latency for this test was $30 \mathrm{~s}$ (Mika et al., 2015).

\section{In Situ Hybridization}

After sacrifice, the brains were removed and frozen on dry ice. They were then cut into $12-\mu \mathrm{m}$ thick coronal sections on a cryostat microtome (CM 3050S Leica, Nussloch, Germany), the sections were thaw-mounted on gelatin-chrome alumcoated or Superfrost ${ }^{\circledR}$ Plus microscope slides (Gerhard Menzel, Braunschweig, Germany) and processed for ISH according to the method of Young et al. (1986). Briefly, the sections were fixed with $4 \%$ paraformaldehyde, washed in PBS and acetylated by incubation with $0.25 \%$ acetic anhydrite (in $0.1 \mathrm{M}$ triethanolamine and $0.9 \%$ sodium chloride). The sections were then dehydrated using increasing concentrations of ethanol (70-100\%), treated with chloroform for $5 \mathrm{~min}$, and rehydrated with decreasing concentrations of ethanol.

The sections were hybridized for approximately $15 \mathrm{~h}$ at $37{ }^{\circ} \mathrm{C}$ with oligonucleotide probes for PENK, PDYN, or the dopamine D2 receptor mRNAs. The probes for the opioid propeptides were complementary to residues $388-435$ and 862-909 of the rat PENK and PDYN gene transcripts, respectively (Yoshikawa et al. 1984; GenBank: K02807.1; Civelli et al. 1985; GenBank: M10088.1). Each probe contained one mismatch with respect to the corresponding mouse sequence (Zurawski et al. 1986; GenBank: NM_018863.2). The D2 receptor probe was complementary to residues 553-600 of the mouse D2 receptor mRNA (Short et al. 2006; NM_010077.1). All probes were labeled with ${ }^{35}$ S-dATP (Perkin Elmer, Waltham, MA, USA) by the 3'-tailing reaction using terminal transferase (MBI Fermentas, Vilnius, Lithuania).

After hybridization, the slices were washed three times for 20 min with $1 \times \mathrm{SSC} / 50 \%$ formamide at $40{ }^{\circ} \mathrm{C}$ and twice for 50 min with $1 \times \mathrm{SSC}$ at room temperature. Then, the slices were dried and exposed to Fujifilm (Tokyo, Japan) phosphorimager imaging plates for 5 to 6 days. The hybridization signal was digitized using the Fujifilm BAS-5000 phosphorimager and Image Reader software.

\section{Image Analysis}

The ISH signal was analyzed using the MCID Elite system (Imaging Research, St. Catharines, Ontario, Canada). Mean signal density, expressed in photostimulated luminescence units $/ \mathrm{mm}^{2}$, was measured in selected brain regions in the Fujifilm BAS-5000 images. The regions included the anterior dorsal striatum (dStr), nucleus accumbens (NAc) core and shell (for PENK, PDYN, and the D2 receptor), substantia 
nigra pars compacta $(\mathrm{SNc})$, and the ventral tegmental area (VTA) (for the D2 receptor only). The brain regions were delineated as previously (Ziolkowska et al. 2008; MartínGarcía et al. 2011) at coronal levels Bregma +1.1 to 1.42 for the dStr and NAc, and Bregma -2.92 to -3.16 for the SNc and VTA (Paxinos and Franklin 2001). For each brain structure, data were collected from at least two sections per animal, separately for the brain side ipsilateral and contralateral to the injured nerve. The background signal, measured over brain section parts having the lowest optical density, was subtracted from the hybridization signal in the regions of interest.

\section{RNA Preparation and qRT-PCR}

The brains were removed immediately after decapitation. They were transected along the sagittal fissure; the septum and the medial frontal cortex were pulled away to expose the interior of the lateral ventricle and the caudate putamen. A vertical cut was then made ventrally at the level of the anterior commissure and the tissue surrounding the commissure (nucleus accumbens) was pulled out using fine forceps. Tissue samples containing ipsilateral and contralateral nucleus accumbens were collected separately. They were placed in individual tubes with the tissue storage reagent RNAlater (Qiagen Inc., Valencia, CA, USA) and preserved at $-70{ }^{\circ} \mathrm{C}$. The samples were thawed at room temperature and homogenized in TRIzol reagent (Invitrogen, Carlsbad, CA, USA). RNA isolation was performed in accordance with the manufacturer's protocol. RNA concentration was measured using a NanoDrop ND-1000 Spectrometer (NanoDrop Technologies, Wilmington, DE, USA). Reverse transcription was performed on $1 \mu \mathrm{g}$ of total RNA using Omniscript reverse transcriptase (Qiagen Inc.) at $37^{\circ} \mathrm{C}$ for $60 \mathrm{~min}$ in the presence of RNase inhibitor (rRNAsin; Promega, Madison, WI, USA) and oligo (dT)12-18 primer (Invitrogen).

cDNA was diluted 1:10 with $\mathrm{H}_{2} \mathrm{O}$. PCR was performed using Assay-On-Demand TaqMan probes according to the manufacturer's protocol (Applied Biosystems, Foster City, CA, USA) and run on a real-time PCR iCycler (Bio-Rad, Hercules, CA, USA). The following TaqMan probes were used: Mm01545399_m1 for hypoxanthine guanine phosphoribosyl transferase 1 (HPRT1; Hprt1 gene), Mm00457573_m1 for PDYN (Pdyn gene), Mm01212875_m1 for PENK (Penk gene), Mm01188089_m1 for the MOP receptor (Oprm1 gene), Mm01230885_m1 for the KOP receptor (Oprk1 gene), Mm01180757 for the DOP receptor (Oprdl gene), Mm01353211 for the dopamine D1 receptor (Drdl gene), and Mm00438545 for the dopamine D2 receptor (Drd2 gene). The expression of HPRT1 (a housekeeping gene) was quantified to control for variation in cDNA amounts between samples. Threshold cycle values were calculated automatically by
iCycler IQ 3.0 software with default parameters. The abundance of RNA was calculated as $2^{- \text {(threshold cycle) }}$.

\section{Western Blot}

Ipsilateral and contralateral nucleus accumbens were collected immediately after decapitation on day 14 after CCI (see the previous section for dissection details). The tissue samples were homogenized in RIPA buffer supplemented with a protease inhibitor cocktail. The homogenates were cleared by centrifugation $\left(14,000 \times \mathrm{g}\right.$ for $30 \mathrm{~min}$ at $\left.4{ }^{\circ} \mathrm{C}\right)$, and protein concentration was determined in the supernatant using the BCA Protein Assay Kit (Sigma-Aldrich, St. Louis, MO, USA). All samples ( $20 \mu \mathrm{g}$ of protein from tissue) were heated in a loading buffer $(4 \times$ Laemmli Buffer, Bio-Rad, Hercules, CA, USA) for 8 min at $98^{\circ} \mathrm{C}$. Next, the samples were resolved on $4-20 \%$ Criterion $^{\mathrm{TM}} \mathrm{TGX}^{\mathrm{TM}}$ precast polyacrylamide gels (Bio-Rad) and placed on Immune-Blot PVDF membranes (Bio-Rad) by the method of semidry transfer (30 min, $25 \mathrm{~V})$. Membranes were blocked with 5\% nonfat dry milk (Bio-Rad) in Tris-buffered saline with $0.1 \%$ Tween 20 (TBST) for $1 \mathrm{~h}$ at room temperature, washed with TBST, and incubated overnight at $4{ }^{\circ} \mathrm{C}$ with the following primary antibodies: rat antiD1 (1:200, SantaCruz, sc-31478), rabbit anti-D2 (1:200, SantaCruz, CA, USA, sc-9113), and mouse anti-GAPDH (1:5000, Merck Millipore, Darmstadt, Germany, MAB374). Next, the membranes were incubated with horseradish peroxidase-conjugated anti-goat (1:1000, Vector, CA, USA, PI-9500), anti-rabbit (1:5000, Vector, PI-1000), or antimouse (1:5000, Vector, PI-2000) secondary antibodies for $1 \mathrm{~h}$. We used the solutions from the SignalBoost ${ }^{\mathrm{TM}}$ Immunoreaction Enhancer Kit (Merck Millipore) in order to dilute the primary and secondary antibodies. The membranes underwent washing with TBST twice for $2 \mathrm{~min}$ each, and 3 times for $5 \mathrm{~min}$ each. In the final step, immune complexes were detected with the Clarity ${ }^{\mathrm{TM}}$ Western ECL Substrate (Bio-Rad) and visualized with a Fujifilm LAS-4000 FluorImager system. The relative levels of immunoreactive proteins were quantified densitometrically using the Fujifilm Multi Gauge software. After visualization, blots were washed again 2 times for $5 \mathrm{~min}$ each in TBST and reprobed with an antibody against GAPDH as an internal loading control. The levels of D1 and D2 receptors were normalized to internal references and presented as a ratio to the GAPDH signal.

\section{Statistical Analyses}

The behavioral data are presented as the mean \pm S.E.M. $(n=$ 10 to 11). Intergroup differences were analyzed by two-way analysis of variance (ANOVA) considering time and brain side (ipsilateral vs. contralateral to the injury) as factors, which was followed by Bonferroni multiple comparison test. The qRT-PCR data are presented as the mean \pm S.E.M. $(n=8$ to 
10). The results were analyzed using two-way ANOVAs considering treatment (naive vs. $\mathrm{CCI}$ ) and brain side (ipsilateral vs. contralateral to the injury) as factors. The Western blot data are presented as the mean \pm S.E.M. ( $n=4$ to 5 ). The results were evaluated using two-way ANOVAs to determine the effects of treatment and brain side. The ISH data are presented as the mean \pm S.E.M. ( $n=5$ to 6 ). The results were analyzed by three-way ANOVAs in which the brain region was considered an additional factor. In all the analyses, $p \leq 0.05$ was considered an indication of statistical significance.

\section{Results}

\section{The Influence of $\mathrm{CCI}$ on Mechanical and Thermal Sensitivity Measured on Days 7 and 14 After Injury}

Pain thresholds in response to mechanical and thermal stimuli were measured by the von Frey and cold plate tests, respectively. CCI produced dramatic decreases in pain thresholds in the ipsilateral paw, as determined by both tests at 7 and 14 days after injury (Fig. 1). No changes in the response to both types of stimuli were observed in the contralateral paw at the timepoints examined, as compared with the control group (Fig. 1).

\section{The Influence of $\mathrm{CCl}$ on Opioid Propeptide Gene Expression in the Striatum}

Figure $2 \mathrm{a}$ and $\mathrm{b}$ show the results of the ISH analysis of PENK gene expression in the striatal regions of interest (ROI) performed 7 days after CCI. A three-way ANOVA (treatment $\times$ side $\times$ ROI) revealed an influence of CCI on the expression of the PENK gene, showing significance of the treatment factor ( $p=0.017 ; F=6.068)$ in the absence of significant treatment $\times$ side or treatment $\times$ ROI interactions. These results indicate that CCI produced a bilateral increase in the PENK mRNA levels throughout the striatal regions tested, encompassing the dStr, NAc shell, and NAc core (Fig. 2a, b).

PENK gene expression was further studied using qRT-PCR (Fig. 2c). To assess the effects of longer-lasting pain, which could affect striatal gene transcription more profoundly, qRTPCR measurements were performed 14 days after CCI; the measures of neuropathic pain, tactile, and thermal hypersensitivity remain at comparable levels between days 7 and 14 after CCI in mice (Fig. 1; Mika et al. 2009, 2015; Rojewska et al. 2018). Extracts of the whole NAc were used for this analysis. Two-way ANOVA (treatment $\times$ side) revealed a significant effect of the treatment factor $(p=0.0055 ; F=8.789)$ on the expression of the PENK gene. Neither the side factor nor the treatment $\times$ side interaction proved significant, indicating a bilateral increase in the PENK transcript levels in the NAc (Fig. 2c).

The PDYN gene was regulated by CCI in a similar fashion as PENK (Fig. 3). Thus, CCI produced a bilateral upregulation of the PDYN gene in striatal regions at 7 days as demonstrated by a three-way ANOVA of the ISH results (significant treatment factor, $p=0.005, F=8.553$; treatment $\times$ side and treatment $\times$ ROI interactions nonsignificant; Fig. 3a, b). Elevated levels of PDYN mRNA were also observed by qRT-PCR in the NAc at 14 days after CCI (Fig. 3c).

\section{The Influence of $\mathrm{CCl}$ on Opioid Receptor Gene Expression in the Striatum}

Due to the low abundance of the opioid receptors transcripts in the striatum and low sensitivity of the ISH method applied, expression of these receptors was assessed only by qRT-PCR. CCI produced bilateral upregulation of the DOP and KOP receptor transcripts in the NAc at 14 days $(p=0.0172, F=$ 6.31 and $p=0.0023, F=10.34$ for the treatment factor, respectively), whereas the level of the MOP receptor transcript remained unchanged (Fig. 4).

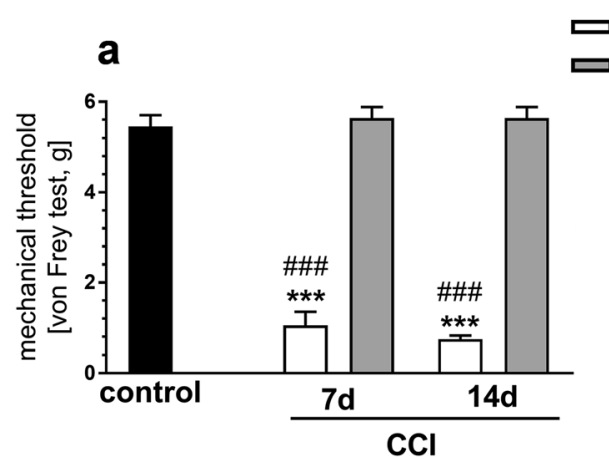

Fig. 1 The effect of chronic constriction injury (CCI) on sensitivity to mechanical and thermal stimuli at 7 and 14 days after injury. a Sensitivity to mechanical stimuli as measured by the von Frey test. b Sensitivity to thermal stimuli as measured by the cold plate test. The data are presented as the mean ( \pm S.E.M.) $(n=10$ to 11$)$. Intergroup differences were psi contra b

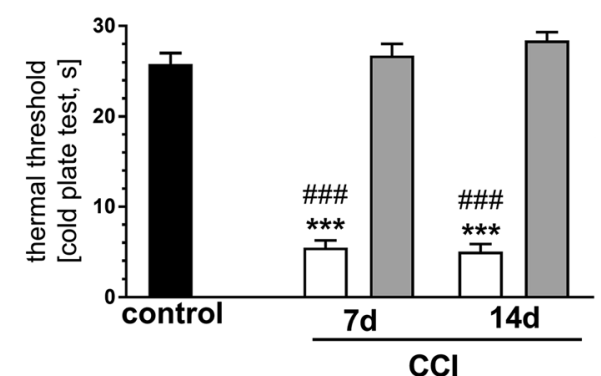

analyzed by two-way ANOVA followed by Bonferroni multiple comparison test. Triple asterisks indicate a significant difference compared with the control (naive) animals $(p<0.001)$. Triple number sign indicates a significant difference compared with the contralateral side on the same day after CCI $(p<0.001)$ 


\section{PENK}
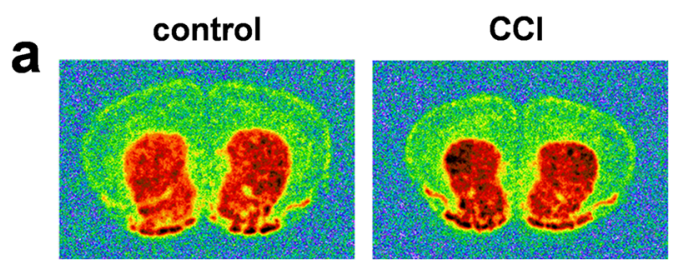

b

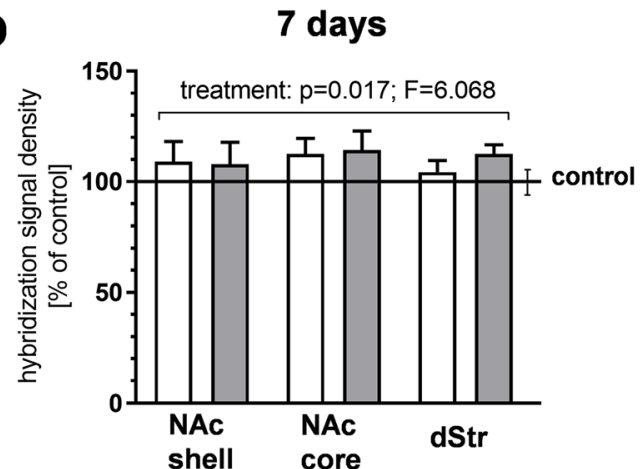

hybridization signal

density $\left[\mathrm{PSL} / \mathrm{mm}^{2}\right]$

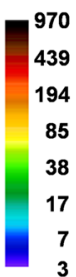

C

14 days

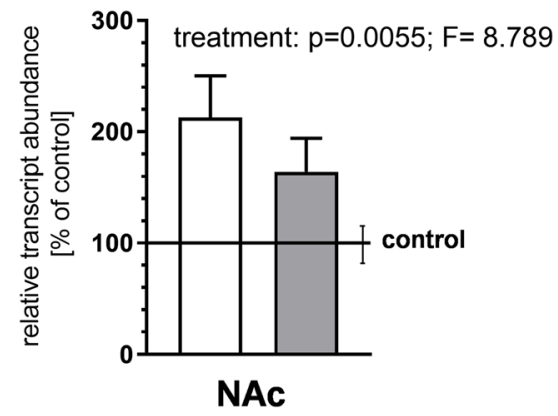

Fig. 2 The effect of chronic constriction injury (CCI) on proenkephalin (PENK) gene expression in the striatum/nucleus accumbens. a, b An in situ hybridization analysis of PENK gene expression at 7 days after CCI. Panel a shows representative autoradiograms, where optical densities are color-coded according to the scale on the right (PSL, photostimulated luminescence units). The bars in panel $\mathbf{b}$ represent the mean ( \pm S.E.M.) optical densities in the indicated brain regions of the CCI group $(n=6)$, ipsilateral and contralateral to the injured nerve. The data are expressed as a percentage of the corresponding values in the naive control group $(n=$ 5 ). The control is indicated by the horizontal line at $100 \%$, and the vertical error bar on the right-hand side of this line represents the mean S.E.M. in the control group. $p$ and $F$ values above the bars are the results of a three-

\section{The Influence of CCl on Dopamine Receptor mRNA and Protein Levels in the Mesostriatal System}

Considering the high expression of the dopamine D2 receptor in mesencephalic dopamine neurons, the levels of D2 receptor mRNA were assessed by ISH in the SNc and VTA in addition to the striatal regions (Fig. 5a, b). Three-way ANOVA (treatment $\times$ side $\times$ ROI) revealed the significance of both treatment factor and treatment $\times$ ROI interaction (but not of the treatment $\times$ side interaction), thus demonstrating differential regional regulation of the D2 receptor mRNA levels at 7 days after CCI (Fig. 5b). To make the analysis comparable with that performed for the other genes, we then carried out ANOVAs separately for the striatal regions (NAc shell, core and dStr, as in the case of PENK and PDYN) and mesencephalic regions (SNc and VTA). The effect of the treatment was not significant by a three-way ANOVA considering only the striatal regions, even though a tendency toward an increase in the D2 receptor mRNA levels was observed in the NAc. In contrast, a significant decrease in D2 receptor expression was detected in the mesencephalic regions $(p=0.0003, F=$ 16.205 for the treatment factor; Fig. 5b). The lack of a way ANOVA (treatment $\times$ side $\times$ region of interest $[\mathrm{ROI}]$ ). All other results of this ANOVA, not shown in the figure, were nonsignificant, except for the ROI factor (which reflected differences in the level of PENK gene expression between brain regions). $\mathbf{c}$ qRT-PCR measurements of PENK mRNA levels in the nucleus accumbens at 14 days after CCI. Data represent the mean $( \pm$ S.E.M.) PENK transcript abundance standardized against HPRT1 transcript and expressed as percentage of control (see description of panel $\mathbf{b}$ ); $n=8$ to $10 . p$ and $F$ values above the bars are the results of a two-way ANOVA (treatment $\times$ side). The side factor and treatment $\times$ side interaction were nonsignificant. The ANOVAs were performed on raw data. dStr, dorsal striatum; NAc, nucleus accumbens

significant treatment $\times$ side interaction in this analysis suggested that the effect was bilateral.

A two-way ANOVA of qPCR measurements at 14 days after CCI demonstrated a bilateral increase in the $\mathrm{D} 2$ receptor mRNA levels in the NAc $(p=0.0247, F=5.512$ for the treatment factor and nonsignificant treatment $\times$ side interaction; Fig. 5d). This was accompanied by an increase in the protein level of the D2 receptor, as determined by Western blot at the same time-point ( $p=0.0016, F=22.45$ for the treatment factor and nonsignificant treatment $\times$ side interaction; Fig. $5 f$ ).

An increase in mRNA levels was also observed for the D1 receptor in the NAc $(p=0.05, F=4.105$ for the treatment factor; Fig. 5c). However, the levels of the corresponding protein remained unchanged in the NAc at 14 days (Fig. 5e).

\section{Discussion}

Our results demonstrated that chronic constriction sciatic nerve injury produced increases in gene expression of the dopamine and opioid receptors, as well as opioid propeptides, in the NAc. They also suggested that at least some of these 


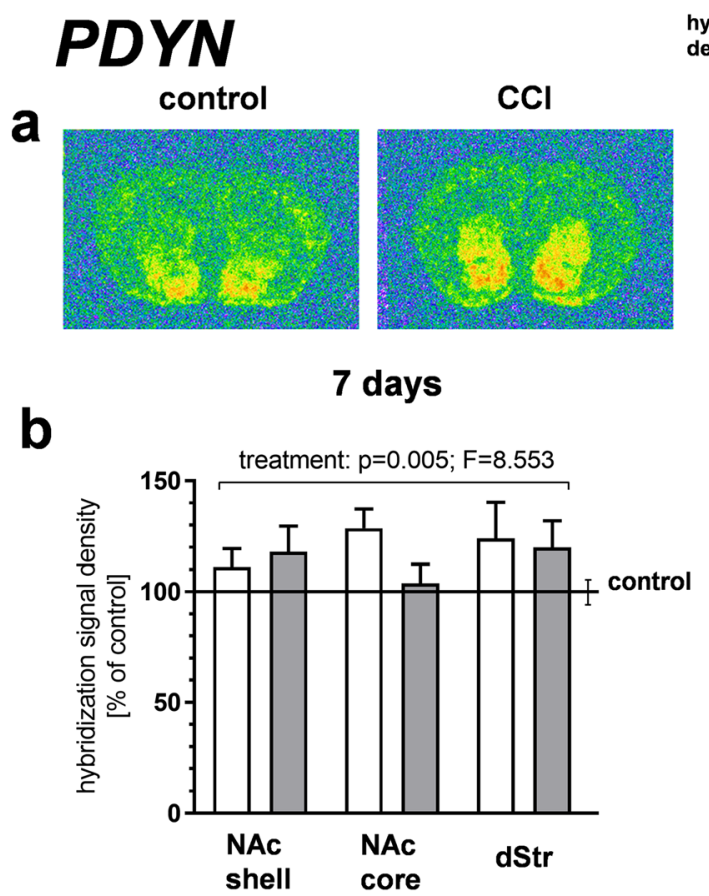

hybridization signa

density $\left[\mathrm{PSL} / \mathrm{mm}^{2}\right]$
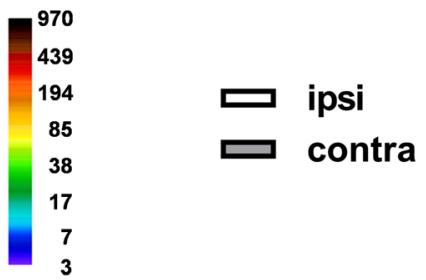

C

14 days

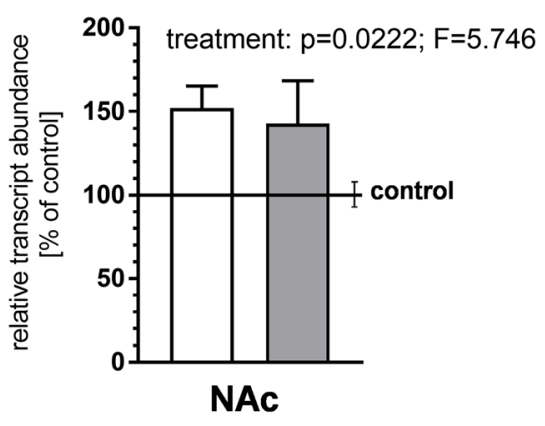

Fig. 3 The effect of chronic constriction injury (CCI) on prodynorphin (PDYN) gene expression in the striatum/nucleus accumbens. a, b An in situ hybridization analysis of PDYN gene expression at 7 days after CCI. Panel a shows representative autoradiograms, where optical densities are color-coded according to the scale on the right (PSL, photostimulated luminescence units). The bars in panel b represent the mean ( \pm S.E.M.) optical densities in the indicated brain regions of the CCI group $(n=6)$, ipsilateral and contralateral to the injured nerve. The data are expressed as a percentage of the corresponding values in the naive control group $(n=$ 5 ). The control is indicated by the horizontal line at $100 \%$, and the vertical error bar on the right-hand side of this line represents the mean S.E.M. in the control group. $p$ and $F$ values above the bars are the results of a three-

genes were upregulated in the dStr as well. In addition, painrelated transcriptional alterations seemed to occur not only in the target regions of the dopaminergic mesostriatal pathways but also in the dopaminergic neurons themselves, as exemplified by downregulated levels of the $\mathrm{D} 2$ receptor mRNA in the VTA and SNc of mice subjected to CCI. way ANOVA (treatment $\times$ side $\times$ region of interest [ROI]). All other results of this ANOVA, not shown in the figure, were nonsignificant, except for the ROI factor (which reflected differences in the level of PDYN gene expression between brain regions). $\mathbf{c}$ qRT-PCR measurements of PDYN mRNA levels in the nucleus accumbens at 14 days after CCI. Data represent the mean $( \pm$ S.E.M.) PDYN transcript abundance standardized against HPRT1 transcript and expressed as percentage of control (see description of panel b); $n=8$ to 10. $p$ and $F$ values above the bars are the results of a two-way ANOVA (treatment $\times$ side). The side factor and treatment $\times$ side interaction were nonsignificant. The ANOVAs were performed on raw data. dStr, dorsal striatum; NAc, nucleus accumbens

Decreased dopamine signaling in the mesolimbic system has been reported in neuropathic pain models, including decreased dopaminergic cell firing, extracellular dopamine levels in the NAc, and reactivity to rewarding stimuli (Ozaki et al. 2002; Taylor et al. 2014; Wu et al. 2014; Ren et al. 2016). The function of dopamine neurons is regulated by dopamine
MOP

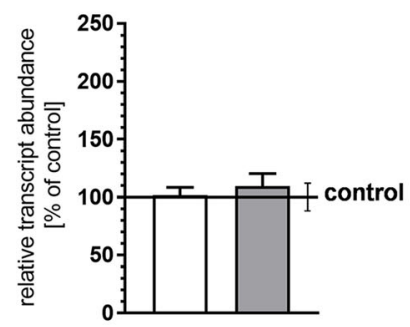

Fig. 4 The effect of chronic constriction injury (CCI) on MOP, DOP, and $\mathrm{KOP}$ opioid receptor gene expression in the nucleus accumbens. The bars show the results of qRT-PCR measurements of MOP, DOP, and KOP mRNA levels in the nucleus accumbens at 14 days after CCI. Data represent the mean ( \pm S.E.M.) transcript abundance standardized against HPRT1 transcript and expressed as percentage of control. The control is
KOP
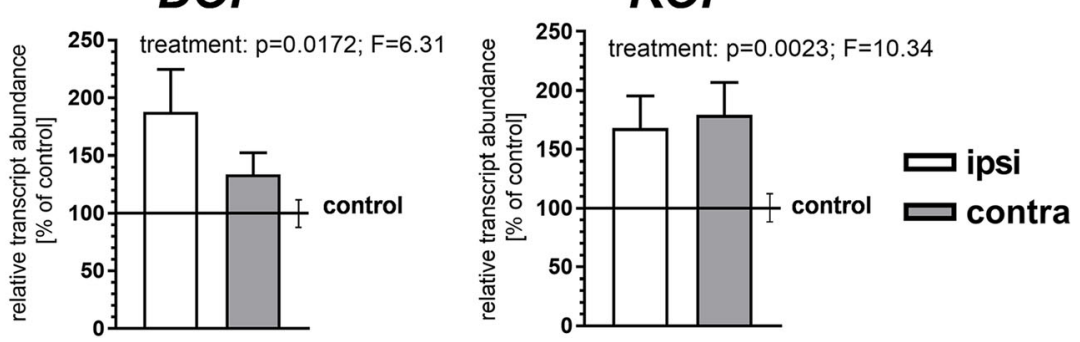

indicated by the horizontal line at $100 \%$, and the vertical error bars on the right-hand side of these lines represent the mean S.E.M. in the control group; $n=8$ to 10. $p$ and $F$ values above the bars are the results of a twoway ANOVA (treatment $\times$ side). The side factor and treatment $\times$ side interactions were nonsignificant. ANOVAs were performed on raw data 

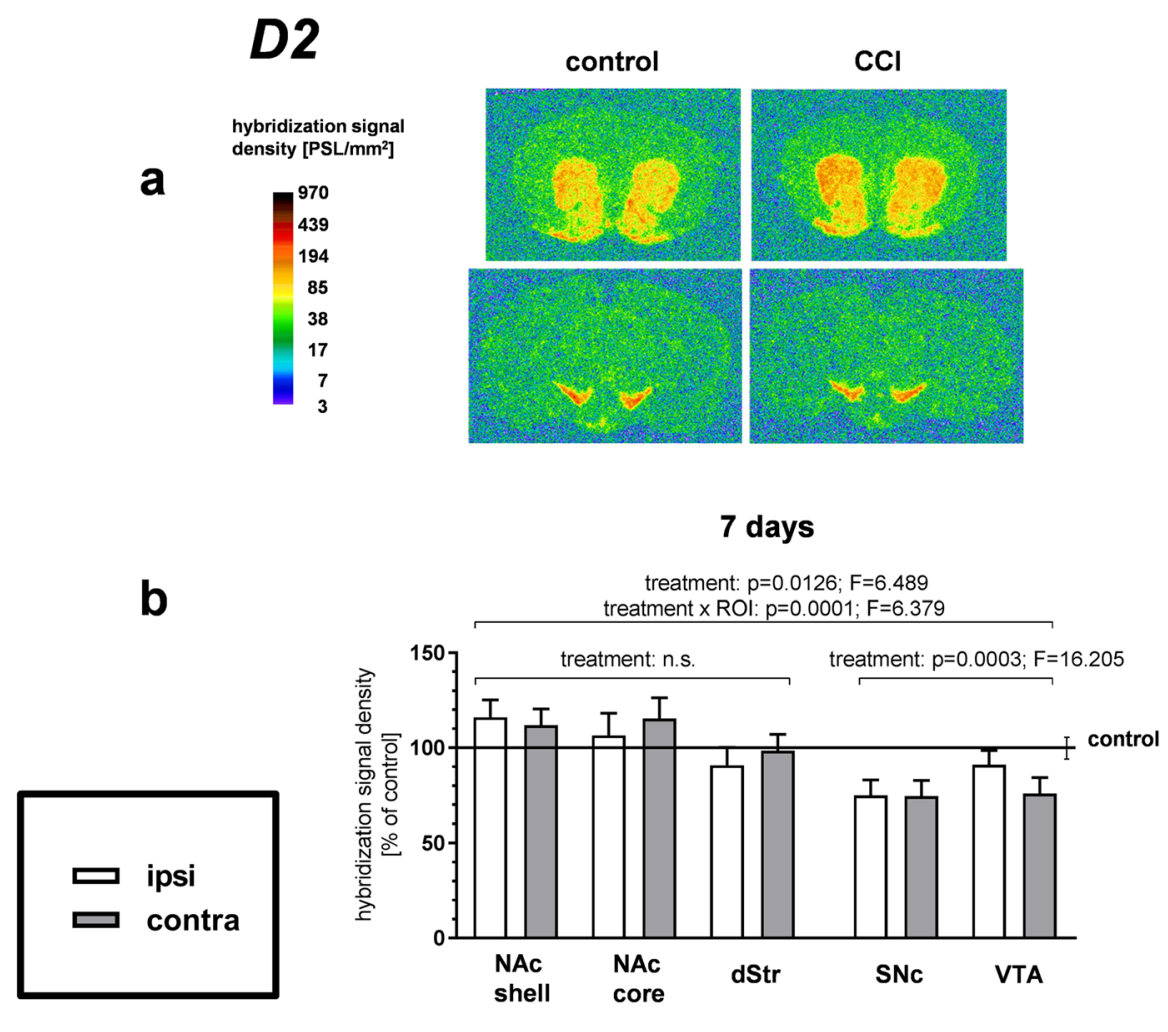

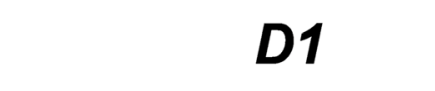

14 days

C

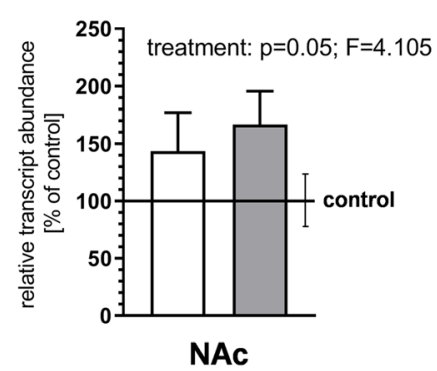

e
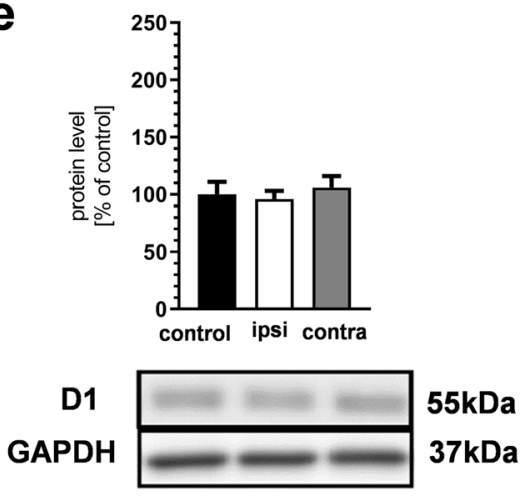

NAC

via inhibitory somatodendritic and axonal D2 autoreceptors, whose stimulation limits dopaminergic cell firing and neurotransmitter release (cf. Ford 2014). Thus, the downregulation

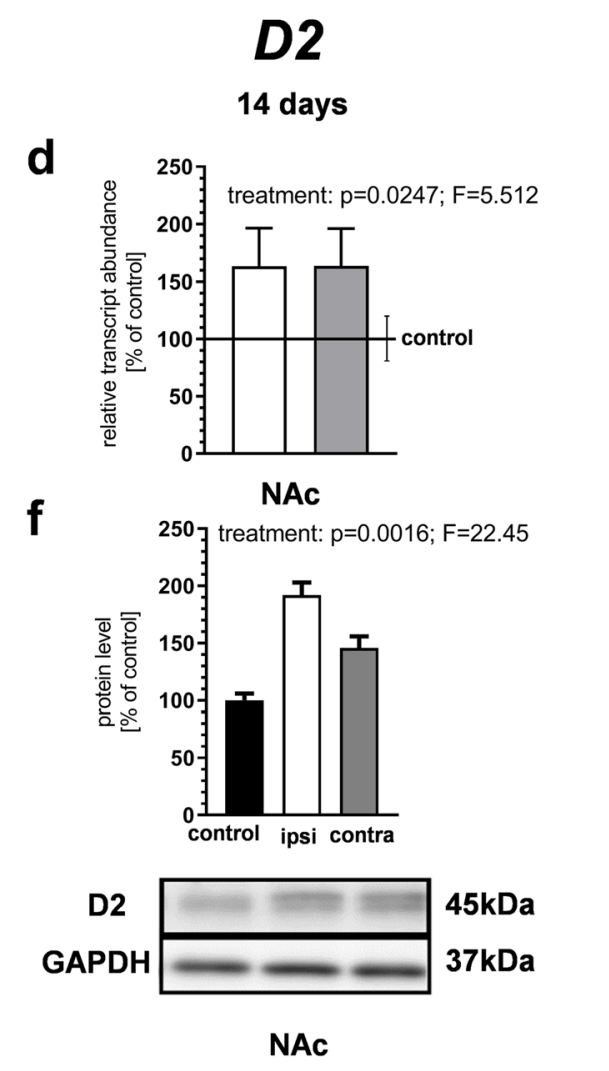

of the D2 receptor gene in mesencephalic dopaminergic cell body regions observed in our study can be regarded as a potential compensatory change, provided that it translates into a 
4 Fig. 5 The effect of chronic constriction injury (CCI) on the dopamine $\mathrm{D} 1$ and $\mathrm{D} 2$ receptor mRNA and protein levels in the mesostriatal system. a, b An in situ hybridization analysis of D2 receptor gene expression at 7 days after CCI. Panel a shows representative autoradiograms, where optical densities are color-coded according to the scale on the left (PSL, photostimulated luminescence units). The bars in panel $\mathbf{b}$ represent the mean $( \pm$ S.E.M.) optical densities in the indicated brain regions of the CCI group $(n=6)$, ipsilateral and contralateral to the injured nerve. The data are expressed as a percentage of the corresponding values in the naive control group $(n=5)$. The control is indicated by the horizontal line at $100 \%$, and the vertical error bar on the right-hand side of this line represents the mean S.E.M. in the control group. $p$ and $F$ values above the bars are the results of three-way ANOVAs (treatment $\times$ side $\times$ region of interest $[\mathrm{ROI}])$. All other results of these ANOVAs, not shown in the figure, were nonsignificant, except for the ROI factor (which reflected differences in the level of the D2 receptor gene expression between brain regions). c, d qRT-PCR measurements of the D1 and D2 receptor mRNA levels in the nucleus accumbens at 14 days after CCI. Data represent the mean $( \pm$ S.E.M. $)$ transcript abundance standardized against HPRT1 transcript and expressed as percentage of control (see description of panel $\mathbf{b}) ; n=8$ to 10. $p$ and $F$ values above the bars are the results of two-way ANOVAs (treatment $x$ side). The side factor and treatment $x$ side interaction were nonsignificant. e, f Western blot measurements of the $\mathrm{D} 1$ and $\mathrm{D} 2$ receptor protein levels in the nucleus accumbens at 14 days after CCI. Data represent the mean ( \pm S.E.M.) expressed as percentage of control; $n=4$ to 5. $\mathrm{p}$ and $F$ values above the bars are the results of twoway ANOVAs (treatment $\times$ side). The side factor and treatment $\times$ side interaction were nonsignificant in both cases. For the D1 receptor, the treatment factor was also nonsignificant. All ANOVAs were performed on raw data. dStr, dorsal striatum; NAc, nucleus accumbens; SNc, substantia nigra pars compacta; VTA, ventral tegmental area

corresponding drop in functional protein levels. It could act to partially restore dopamine system function by limiting the D2 receptor-mediated autoinhibitory control of dopamine over its neurons. Interestingly, similar changes in the D2 receptor mRNA levels were reported in the VTA and SNc after chronic treatment of rats with other stressful procedures, which did not include painful stimuli (Dziedzicka-Wasylewska et al. 1997).

Upregulation of postsynaptic D1 and D2 receptors in the NAc observed in our study after CCI could have a similar net effect of compensating for the deficient neurotransmission by the presynaptic dopaminergic neurons. Nevertheless, our measurements of the receptor protein levels in the NAc indicate that only the D2 (but not D1) receptor may actually play such a role. This is because, in contrast to the D2 receptor protein abundance, which increased in the NAc after CCI, the D1 receptor protein level remained unchanged (despite upregulation of the corresponding mRNA). Other studies regarding expression of the accumbal dopamine receptors in rodent models of neuropathy yielded inconsistent results demonstrating upregulation, downregulation, or lack of change in the D1 and D2 receptor mRNA and/or protein expression (Austin et al. 2010; Chang et al. 2014; Sagheddu et al. 2015). Importantly, the work by Chang et al. (2014) suggested that regulation of these receptors expression may depend on the duration of pain, which may explain major differences in results obtained using various experimental paradigms.

Similar to other parts of the striatum, the NAc is composed mainly of GABAergic projection medium spiny neurons (MSN). They comprise two major cell classes, one of which (D1-MSN) is characterized by the expression of the dopamine D1 receptor, substance $\mathrm{P}$, and the opioid propeptide PDYN, as well as by a predominant projection to the mesencephalon (the so-called direct striatofugal pathway). The other MSN type (D2-MSN) is characterized by the expression of the D2 receptor and the opioid propeptide PENK, and by a predominant projection to the pallidum (the so-called indirect pathway) (Gerfen et al. 1990; Gerfen 1992; Sesack and Grace 2010). While the expression of these receptors and neuropeptides is strongly segregated in the dStr, the NAc contains a larger proportion of neurons of mixed molecular phenotypes and projection targets (Curran and Watson 1995; Zhou et al. 2003; Perreault et al. 2010; Kupchik et al. 2015).

Our experiment demonstrated that markers of both striatofugal pathways (D1 receptor and PDYN, as well as $\mathrm{D} 2$ receptor and $\mathrm{PENK}$ ) are upregulated at the transcriptional level in the CCI model of neuropathic pain in the NAc. Due to differences in D1 vs. D2 receptor coupling, dopamine exerts opposite effects on the two striatal MSN populations: it stimulates D1-MSN and inhibits D2-MSN (Gerfen and Surmeier 2011). The neuropathic pain-related decrease in dopaminergic tone could lead to disinhibition of the D2-MSN via the D2 receptor and contribute to the observed increases in the D2 receptor and PENK mRNA levels. In fact, these two genes are known to be upregulated in the dStr by dopamine deficiency or by blockade of the D2 receptor (Young et al. 1986; Gerfen et al. 1990; Reimer et al. 1992). On the other hand, some markers of the D1-MSN, including the PDYN gene, are positively regulated by dopamine via the D1 receptor (Berke et al. 1998; Gerfen et al. 1990; Reimer et al. 1992). Thus, their upregulation in the neuropathic pain model used in our experiments cannot be attributed to the decreased dopaminergic tone.

Upregulation of the dopamine receptors and opioid propeptides mRNAs in both subpopulations of MSN could result from alterations in glutamatergic neurotransmission. The NAc is densely innervated by glutamatergic afferents that impinge on all MSNs (Ghasemzadeh et al. 1996; Sesack and Grace 2010). In chronic neuropathic and inflammatory pain models, increased synaptic levels of the specific GluA1-rich AMPA glutamate receptors, which are permeable to calcium ions, were reported in the NAc (Goffer et al. 2013; Su et al. 2015). It seems plausible that increased calcium influx into the MSN via these receptors might promote $\mathrm{Ca}^{2+}$-dependent transcriptional mechanisms, including activation of the transcription factor CREB (cAMP response element binding protein) (Ginty 1997; Perkinton et al. 1999), and result in upregulation 
of its target genes, such as PDYN and PENK (Konradi et al. 1993, 1995; Cole et al. 1995).

The increased levels of transcripts characteristic of both the direct and indirect striatofugal pathway suggest that the net excitatory input to D1-MSN and D2-MSN is strengthened after CCI and thus indicates that both efferent pathways originating in the striatum might be overactive in the neuropathic pain model. Whereas the role of the direct pathway and the accumbal D1 receptor in pain perception is not clear, ample evidence shows that activity of the indirect pathway D2-MSN in the NAc is important for chronic pain sensation. Namely, targeting this neuronal population by a chemogenetic method or selective D2 receptor ligands demonstrated that stimulation of the indirect pathway exerted proalgesic effects, whereas its inhibition reduced mechanical and thermal hypersensitivity in neuropathic pain and formalin models (Altier and Stewart 1993, 1998; Magnusson and Fisher 2000; Ansah et al. 2007; Cobacho et al. 2014; Ren et al. 2016). Thus, our results suggest that peripheral neuropathy affects the accumbal indirect pathway D2-MSN activity in such a manner that it can enhance the perception of pain.

The opioid propeptide genes PDYN and PENK were upregulated in the NAc of CCI-subjected animals in our study. Moreover, the expression of the KOP and DOP receptors, which are the preferential binding targets for PDYN- and PENK-derived peptides, respectively, was also increased at the transcriptional level. These observations suggest that endogenous opioid signaling within the NAc might be strengthened in neuropathic pain.

This is in contrast to our previous observations of decreased expression and activity (GTP $\gamma \mathrm{S}$ binding) of opioid receptors in the spinal cord and thalamus of mice subjected to the same CCI procedure, accompanied by upregulation of the spinal PENK and PDYN genes (Rojewska et al. 2018). Studies in different experimental settings also yielded some contrasting results regarding regulation of opioid receptors in animal models of neuropathic pain. For example, in rat models, decreased mRNA levels of the DOP and KOP receptor were reported in the NAc at delayed time-points ( 1 month) but not at 1 week after nerve injury (Llorca-Torralba et al. 2020 and Chang et al. 2014, respectively). However, these gene expression changes were not paralleled by analogous changes in agoniststimulated receptor activity (GTP $\gamma \mathrm{S}$ binding), although the latter was altered in a manner apparently independent on the corresponding receptor transcript levels (LlorcaTorralba et al. 2020). On the other hand, consistent with our results, elevation of both KOP receptor mRNA and agonist-stimulated activity was demonstrated in the mouse at 14 days after peripheral nerve injury (Liu et al. 2019). Discrepancies in the existing data indicate the necessity of further research into the regulation of the striatal opioid receptors by chronic pain.
Interestingly, the changes demonstrated by our group in the spinal cord and thalamus, which contain components of the somatosensory pathways, were unilateral and limited to the side conveying the ascending nociceptive information from the injured hindpaw nerve (Rojewska et al. 2018). In contrast, all changes detected in the present study in the striatum/NAc were bilateral, consistent with the concept of the NAc (and its local opioids) involvement in a more generalized control over pain thresholds and the affective aspect of pain (Baliki and Apkarian 2015; Borsook et al. 2016).

The best characterized effect of striatal dynorphins is the inhibition of dopamine release via stimulation of the KOP receptor located on dopaminergic axon terminals (Di Chiara and Imperato 1988; Spanagel et al. 1992). This mechanism has been considered responsible for the fact that KOP receptor agonists produce aversion and anhedonia (Bals-Kubik et al. 1989; Knoll and Carlezon Jr 2010; Tejeda et al. 2012). These affective disturbances are common to chronic pain conditions, and deficits of natural and drug reward are observed in animal models thereof (Suzuki et al. 1999; Narita et al. 2005; Borsook et al. 2016). Moreover, pain-related reward deficits could be reversed by intra-NAc infusions of a KOP receptor antagonist or an antibody against dynorphin (Suzuki et al. 1999; Narita et al. 2005). Therefore, it has been posited that protracted pain might be associated with an increase in endogenous dynorphin/KOP receptor signaling in the NAc (Niikura et al. 2010; Borsook et al. 2016; Massaly et al. 2016). Our results provide a potential molecular mechanism for this proposal by demonstrating increased expression of the accumbal PDYN gene in the CCI model of neuropathic pain, which presumably results in elevated levels of available striatal dynorphins (Massaly et al. 2019). Even though some other studies did not reveal such changes (Chang et al., 2014; Leitl et al. 2014; Palmisano et al. 2018), our observation is in line with the very recent papers by Liu et al. (2019) and Massaly et al. (2019). The latter two studies also provide functional evidence for the role of the increased mesolimbic dynorphin/KOP receptor signaling in mediating the tonic aversive component of neuropathic and inflammatory pain. Accordingly, our previous experiments in inbred mouse strains have demonstrated that high levels of PDYN mRNA in the dStr/NAc may be associated with low sensitivity to drug reward (Gieryk et al. 2010).

The proposed role of striatal dynorphins in chronic pain consists of attenuation of dopamine release via the presynaptic KOP receptor (Narita et al. 2005; Massaly et al. 2016). However, our experiment suggests that other mechanisms of potentiated dynorphin/KOP receptor signaling could also be involved because, in agreement with Liu et al. (2019), it shows upregulated KOP receptor gene expression in the postsynaptic (rather than the dopaminergic presynaptic) neurons of the NAc. According to the recent study by Tejeda et al. (2017), stimulation of the KOP receptor located on MSN collaterals in 
the NAc, in addition to those expressed by glutamatergic afferents from the basolateral amygdala, led to a selective disinhibition of the accumbal D2-MSN. Since the activity of this neuronal population is linked to thermal and mechanical hypersensitivity in persistent pain models (see above), it is tempting to speculate that the CCI-produced PDYN and KOP receptor gene expression changes may contribute to the increased pain sensitivity. However, the KOP receptor is expressed by several types of neurons in the NAc, including both MSN populations and some interneurons (Oude Ophuis et al. 2014; Tejeda et al. 2017). Knowledge of the cell types that overexpress the KOP receptor in chronic pain, not available at present, would be crucial for predicting the effects of its upregulation on specific neuronal circuits activity.

In contrast to the effects of dynorphins in the Str/NAc, increased expression of PENK and its derived peptides acting on the MOP and DOP receptors can function as a negative feedback mechanism to limit the excessive stimulation of the striatopallidal pathway D2-MSN due to chronic pain-related deficiency in dopaminergic signaling. Such a feedback mechanism may operate on several levels, involving enkephalins' actions within the Str/NAc (i) on the corticostriatal glutamatergic terminals, whereby enkephalins reduce glutamate release and the resulting postsynaptic excitation of the striatal MSN (Jiang and North 1992; Miura et al. 2007), as well as (ii) on D2-MSN dendrites and somata containing MOP and DOP receptors (Oude Ophuis et al. 2014; Banghart et al. 2015), whereby enkephalins can prevent, e.g., transcriptional activation of these neurons resulting from D2 receptor blockade (Steiner and Gerfen 1999). Enkephalins can also hamper neurotransmission by the striatopallidal MSN by acting on their axon terminals in the ventral pallidum. These terminals contain MOP receptors (Olive et al. 1997), whose stimulation by exogenous or endogenous agonists seems to reduce the release of GABA, i.e., the main neurotransmitter in the striatopallidal pathway (Kupchik et al. 2014). Considering that overactivity of this pathway exacerbates chronic pain, enhanced enkephalin signaling via the MOP and DOP receptors (resulting from increased expression of both PENK and DOP, but not MOP, receptor genes) is expected to produce some analgesia in the CCI model used in our experiments. Such a role of endogenous enkephalins is supported by the observation of analgesic actions of MOP and DOP receptor agonists administered locally into either the NAc or the pallidum (Dill and Costa 1977; Schmidt et al. 2002; Anagnostakis et al. 1992). Nevertheless, it is clear that pronociceptive mechanisms recruited concomittantly in the NAc, as well as in other parts of the nervous system during neuropathy, prevail over the antinociceptive actions likely exerted by enkephalins.

Altogether, we posit that the demonstrated changes in gene expression of the opioid propeptides and their respective receptors, i.e., PENK and DOP receptor vs. PDYN and KOP receptor, in neuropathy induced by sciatic nerve injury, may exert opposite influence on pain perception. Increased activity of the PENK/DOP (and MOP) receptor system within the NAc and/or pallidum is likely to suppress pain to some extent but it is apparently dominated by the enhanced PDYN/KOP receptor signaling in the NAc, which probably exacerbates chronic pain and promotes the associated dysphoric emotional disturbances. Thus, we suggest that a disturbed balance between endogenous opioid systems in favor of the pronociceptive one may contribute to the development of mechanical and thermal hypersensitivity in the CCI model of neuropathy.

Funding Information This study was financially supported by the National Science Centre, Poland, grant MAESTRO 2012/06/A/NZ4/ 00028 and OPUS 2018/29/B/NZ7/00082, statutory funds from the Maj Institute of Pharmacology at the Polish Academy of Sciences, and the European Commission FP7 program (\#HEALTH-F2-2013-602891). JS$\mathrm{S}$ and AP are holders of a KNOW scholarship sponsored by the Ministry of Science and Higher Education, Poland. AP is financially supported by the Foundation for Polish Sciences (FNP), the L'Oréal-UNESCO For Women in Science program in Poland.

\section{Compliance with Ethical Standards}

Conflict of Interest The authors declare that they have no conflict of interest.

Ethical Approval All applicable international, national, and institutional guidelines for the care and use of animals were followed. All procedures performed in studies involving animals were in accordance with the ethical standards of the institution at which the studies were conducted. The experimental protocol was approved by the Local Bioethics Committee (Krakow, Poland, permission number 1214/2015). This article does not contain any studies with human participants performed by any of the authors.

Open Access This article is licensed under a Creative Commons Attribution 4.0 International License, which permits use, sharing, adaptation, distribution and reproduction in any medium or format, as long as you give appropriate credit to the original author(s) and the source, provide a link to the Creative Commons licence, and indicate if changes were made. The images or other third party material in this article are included in the article's Creative Commons licence, unless indicated otherwise in a credit line to the material. If material is not included in the article's Creative Commons licence and your intended use is not permitted by statutory regulation or exceeds the permitted use, you will need to obtain permission directly from the copyright holder. To view a copy of this licence, visit http://creativecommons.org/licenses/by/4.0/.

\section{References}

Altier N, Stewart J (1993) Intra-VTA infusions of the substance P analogue, DiMe-C7, and intra-accumbens infusions of amphetamine induce analgesia in the formalin test for tonic pain. Brain Res 628: 279-285. https://doi.org/10.1016/0006-8993(93)90965-P

Altier N, Stewart J (1998) Dopamine receptor antagonists in the nucleus accumbens attenuate analgesia induced by ventral tegmental area substance $\mathrm{P}$ or morphine and by nucleus accumbens amphetamine. 
J Pharmacol Exp Ther 285:208-215 http://jpet.aspetjournals.org/ content $/ 285 / 1 / 208$.long

Anagnostakis Y, Zis V, Spyraki C (1992) Analgesia induced by morphine injected into the pallidum. Behav Brain Res 48:135-143. https://doi. org/10.1016/S0166-4328(05)80149-4

Ansah OB, Leite-Almeida H, Wei H, Pertovaara A (2007) Striatal dopamine $\mathrm{D} 2$ receptors attenuate neuropathic hypersensitivity in the rat. Exp Neurol 205:536-546. https://doi.org/10.1016/j.expneurol.2007. 03.010

Austin PJ, Beyer K, Bembrick AL, Keay KA (2010) Peripheral nerve injury differentially regulates dopaminergic pathways in the nucleus accumbens of rats with either 'pain alone' or 'pain and disability'. Neuroscience 171:329-343. https://doi.org/10.1016/j.neuroscience. 2010.08.040

Baliki MN, Apkarian AV (2015) Nociception, pain, negative moods, and behavior selection. Neuron 87:474-491. https://doi.org/10.1016/j. neuron.2015.06.005

Baliki MN, Geha PY, Fields HL, Apkarian AV (2010) Predicting value of pain and analgesia: nucleus accumbens response to noxious stimuli changes in the presence of chronic pain. Neuron 66:149-160. https://doi.org/10.1016/j.neuron.2010.03.002

Bals-Kubik R, Herz A, Shippenberg TS (1989) Evidence that the aversive effects of opioid antagonists and kappa-agonists are centrally mediated. Psychopharmacology 98:203-206

Banghart MR, Neufeld SQ, Wong NC, Sabatini BL (2015) Enkephalin disinhibits mu opioid receptor-rich striatal patches via delta opioid receptors. Neuron 88:1227-1239. https://doi.org/10.1016/j.neuron. 2015.11.010

Basbaum AI, Bautista DM, Scherrer G, Julius D (2009) Cellular and molecular mechanisms of pain. Cell 139:267-284. https://doi.org/ 10.1016/j.cell.2009.09.028

Bennett GJ, Xie YK (1988) A peripheral mononeuropathy in rat that produces disorders of pain sensation like those seen in man. Pain 33:87-107. https://doi.org/10.1016/0304-3959(88)90209-6

Berke JD, Paletzki RF, Aronson GJ, Hyman SE, Gerfen CR (1998) A complex program of striatal gene expression induced by dopaminergic stimulation. J Neurosci 18:5301-5310. https://doi.org/10.1523/ JNEUROSCI.18-14-05301.1998

Borsook D, Linnman C, Faria V, Strassman AM, Becerra L, Elman I (2016) Reward deficiency and anti-reward in pain chronification. Neurosci Biobehav Rev 68:282-297. https://doi.org/10.1016/j. neubiorev.2016.05.033

Breivik H, Collett B, Ventafridda V, Cohen R, Gallacher D (2006) Survey of chronic pain in Europe: prevalence, impact on daily life, and treatment. Eur J Pain 10:287-333. https://doi.org/10.1016/j.ejpain. 2005.06.009

Brischoux F, Chakraborty S, Brierley DI, Ungless MA (2009) Phasic excitation of dopamine neurons in ventral VTA by noxious stimuli. Proc Natl Acad Sci U S A 106:4894-4899. https://doi.org/10.1073/ pnas.0811507106

Budygin EA, Park J, Bass CE, Grinevich VP, Bonin KD, Wightman RM (2012) Aversive stimulus differentially triggers subsecond dopamine release in reward regions. Neuroscience 201:331-337. https://doi.org/10.1016/j.neuroscience.2011.10.056

Bushnell MC, Ceko M, Low LA (2013) Cognitive and emotional control of pain and its disruption in chronic pain. Nat Rev Neurosci 14:502 511. https://doi.org/10.1038/nrn3516

Chang PC, Pollema-Mays SL, Centeno MV, Procissi D, Contini M, Baria AT, Martina M, Apkarian AV (2014) Role of nucleus accumbens in neuropathic pain: linked multi-scale evidence in the rat transitioning to neuropathic pain. Pain 155:1128-1139. https://doi.org/10.1016/j. pain.2014.02.019.

Chavkin C, James IF, Goldstein A (1982) Dynorphin is a specific endogenous ligand of the kappa opioid receptor. Science 215:413-415. https://doi.org/10.1126/science.6120570
Civelli O, Douglass J, Goldstein A, Herbert E (1985) Sequence and expression of the rat prodynorphin gene. Proc Natl Acad Sci U S A 82:4291-4295. https://doi.org/10.1073/pnas.82.12.4291

Cobacho N, de la Calle JL, Paíno CL (2014) Dopaminergic modulation of neuropathic pain: analgesia in rats by a D2-type receptor agonist. Brain Res Bull 106:62-71. https://doi.org/10.1016/j.brainresbull. 2014.06.003

Cole RL, Konradi C, Douglass J, Hyman SE (1995) Neuronal adaptation to amphetamine and dopamine: molecular mechanisms of prodynorphin gene regulation in rat striatum. Neuron 14:813-823. https://doi.org/10.1016/0896-6273(95)90225-2e

Curran EJ, Watson SJ Jr (1995) Dopamine receptor mRNA expression patterns by opioid peptide cells in the nucleus accumbens of the rat: a double in situ hybridization study. J Comp Neurol 361:57-76. https://doi.org/10.1002/cne.903610106

Di Chiara G, Imperato A (1988) Opposite effects of mu and kappa opiate agonists on dopamine release in the nucleus accumbens and in the dorsal caudate of freely moving rats. J Pharmacol Exp Ther 244: 1067-1080 http://jpet.aspetjournals.org/content/244/3/1067.long

Dickenson AH, Suzuki R (2005) Opioids in neuropathic pain: clues from animal studies. Eur J Pain 9:113-116. https://doi.org/10.1016/j. ejpain.2004.05.004

Dill RE, Costa E (1977) Behavioural dissociation of the enkephalinergic systems of nucleus accumbens and nucleus caudatus. Neuropharmacology 16:323-326

DosSantos MF, Martikainen IK, Nascimento TD, Love TM, Deboer MD, Maslowski EC, Monteiro AA, Vincent MB, Zubieta JK, DaSilva AF (2012) Reduced basal ganglia $\mu$-opioid receptor availability in trigeminal neuropathic pain: a pilot study. Mol Pain 8:74. https://doi. org/10.1186/1744-8069-8-74

Dziedzicka-Wasylewska M, Willner P, Papp M (1997) Changes in dopamine receptor mRNA expression following chronic mild stress and chronic antidepressant treatment. Behav Pharmacol 8:607-618

Ford CP (2014) The role of D2-autoreceptors in regulating dopamine neuron activity and transmission. Neuroscience 282:13-22. https:// doi.org/10.1016/j.neuroscience.2014.01.025

Geha PY, Baliki MN, Harden RN, Bauer WR, Parrish TB, Apkarian AV (2008) The brain in chronic CRPS pain: abnormal gray-white matter interactions in emotional and autonomic regions. Neuron 60:570 581. https://doi.org/10.1016/j.neuron.2008.08.022

Gerfen CR (1992) The neostriatal mosaic: multiple levels of compartmental organization. Trends Neurosci 15:133-139. https://doi.org/10. 1016/0166-2236(92)90355-C

Gerfen CR, Engber TM, Mahan LC, Susel Z, Chase TN, Monsma FJ Jr, Sibley DR (1990) D1 and D2 dopamine receptor-regulated gene expression of striatonigral and striatopallidal neurons. Science 250: 1429-1432. https://doi.org/10.1126/science.2147780

Gerfen CR, Surmeier DJ (2011) Modulation of striatal projection systems by dopamine. Annu Rev Neurosci 34:441-466. https://doi.org/10. 1146/annurev-neuro-061010-113641

Ghasemzadeh MB, Sharma S, Surmeier DJ, Eberwine JH, Chesselet MF (1996) Multiplicity of glutamate receptor subunits in single striatal neurons: an RNA amplification study. Mol Pharmacol 49:852-859 http://molpharm.aspetjournals.org/content/49/5/852.long

Gieryk A, Ziolkowska B, Solecki W, Kubik J, Przewlocki R (2010) Forebrain PENK and PDYN gene expression levels in three inbred strains of mice and their relationship to genotype-dependent morphine reward sensitivity. Psychopharmacology 208:291-300. https://doi.org/10.1007/s00213-009-1730-1

Gilron I, Baron R, Jensen T (2015) Neuropathic pain: principles of diagnosis and treatment. Mayo Clin Proc 90:532-545. https://doi.org/10. 1016/j.mayocp.2015.01.018

Ginty DD (1997) Calcium regulation of gene expression: isn't that spatial? Neuron 18:183-186. https://doi.org/10.1016/S0896-6273(00) 80258-5 
Goffer Y, Xu D, Eberle SE, D'amour J, Lee M, Tukey D, Froemke RC, Ziff EB, Wang J (2013) Calcium-permeable AMPA receptors in the nucleus accumbens regulate depression-like behaviors in the chronic neuropathic pain state. J Neurosci 33:19034-19044. https://doi.org/ 10.1523/JNEUROSCI.2454-13.2013

Harris RE, Clauw DJ, Scott DJ, McLean SA, Gracely RH, Zubieta JK (2007) Decreased central mu-opioid receptor availability in fibromyalgia. J Neurosci 27:10000-10006. https://doi.org/10.1523/ JNEUROSCI.2849-07.2007

IASP Terminology (2017) The International Association for the Study of Pain website. http://www.iasp-pain.org/Education/Content.aspx? ItemNumber $=1698$.

Jiang ZG, North RA (1992) Pre- and postsynaptic inhibition by opioids in rat striatum. J Neurosci 12:356-361. https:/doi.org/10.1523/ JNEUROSCI.12-01-00356.1992

Knoll AT, Carlezon WA Jr (2010) Dynorphin, stress, and depression. Brain Res 1314:56-73. https://doi.org/10.1016/j.brainres.2009.09. 074

Konradi C, Cole RL, Green D, Senatus P, Leveque J-C, Pollack AE, Grossbard SJ, Hyman SE (1995) Analysis of the proenkephalin second messenger-inducible enhancer in rat striatal cultures. J Neurochem 65:1007-1015. https://doi.org/10.1046/j.1471-4159. 1995.65031007.x

Konradi C, Kobierski LA, Nguyen TV, Heckers S, Hyman SE (1993) The cAMP-response-element-binding protein interacts, but Fos protein does not interact, with the proenkephalin enhancer in rat striatum. Proc Natl Acad Sci U S A 90:7005-7009. https://doi.org/10.1073/ pnas.90.15.7005

Kuner R (2010) Central mechanisms of pathological pain. Nat Med 16: 1258-1266. https://doi.org/10.1038/nm.2231

Kupchik YM, Brown RM, Heinsbroek JA, Lobo MK, Schwartz DJ, Kalivas PW (2015) Coding the direct/indirect pathways by D1 and D2 receptors is not valid for accumbens projections. Nat Neurosci 18:1230-1232. https://doi.org/10.1038/nn.4068

Kupchik YM, Scofield MD, Rice KC, Cheng K, Roques BP, Kalivas PW (2014) Cocaine dysregulates opioid gating of GABA neurotransmission in the ventral pallidum. J Neurosci 34:1057-1066. https://doi. org/10.1523/JNEUROSCI.4336-13.2014

Lapeyre S, Mauborgne A, Becker C, Benoliel JJ, Cesselin F, Hamon M, Bourgoin S (2001) Subcutaneous formalin enhances outflow of metenkephalin- and cholecystokinin-like materials in the rat nucleus accumbens. Naunyn Schmiedeberg's Arch Pharmacol 363:399-406

Leitl MD, Potter DN, Cheng K, Rice KC, Carlezon WA Jr, Negus SS (2014) Sustained pain-related depression of behavior: effects of intraplantar formalin and complete Freund's adjuvant on intracranial self-stimulation (ICSS) and endogenous kappa opioid biomarkers in rats. Mol Pain 10:62. https://doi.org/10.1186/1744-8069-10-62

Liu SS, Pickens S, Burma NE, Ibarra-Lecue I, Yang H, Xue L, Cook C, Hakimian JK, Severino AL, Lueptow L, Komarek K, Taylor AMW, Olmstead MC, Carroll FI, Bass CE, Andrews AM, Walwyn W, Trang T, Evans CJ, Leslie F, Cahill CM (2019) Kappa opioid receptors drive a tonic aversive component of chronic pain. J Neurosci. https://doi.org/10.1523/JNEUROSCI.0274-19.2019

Llorca-Torralba M, Pilar-Cuéllar F, Borges G, Mico JA, Berrocoso E (2020) Opioid receptors mRNAs expression and opioids agonistdependent G-protein activation in the rat brain following neuropathy. Prog Neuropsychopharmacol Biol Psychiatry 99:109857. https://doi.org/10.1016/j.pnpbp.2019.109857

Magnusson JE, Fisher K (2000) The involvement of dopamine in nociception: the role of $\mathrm{D}(1)$ and $\mathrm{D}(2)$ receptors in the dorsolateral striatum. Brain Res 855:260-266. https://doi.org/10.1016/S00068993(99)02396-3

Mansour A, Fox CA, Akil H, Watson SJ (1995) Opioid-receptor mRNA expression in the rat CNS: anatomical and functional implications. Trends Neurosci 18:22-29. https://doi.org/10.1016/0166-2236(95) 93946-U
Martikainen IK, Nuechterlein EB, Peciña M, Love TM, Cummiford CM, Green CR, Stohler CS, Zubieta JK (2015) Chronic back pain is associated with alterations in dopamine neurotransmission in the ventral striatum. J Neurosci 35:9957-9965. https://doi.org/10. 1523/JNEUROSCI.4605-14.2015

Martín-García E, Burokas A, Kostrzewa E, Gieryk A, Korostynski M, Ziolkowska B, Przewlocka B, Przewlocki R, Maldonado R (2011) New operant model of reinstatement of food-seeking behavior in mice. Psychopharmacology 215:49-70. https://doi.org/10.1007/ s00213-010-2110-6

Massaly N, Copits BA, Wilson-Poe AR, Hipólito L, Markovic T, Yoon HJ, Liu S, Walicki MC, Bhatti DL, Sirohi S, Klaas A, Walker BM, Neve R, Cahill CM, Shoghi KI, Gereau RW 4th, McCall JG, AlHasani R, Bruchas MR, Morón JA (2019) Pain-induced negative affect is mediated via recruitment of the nucleus accumbens kappa opioid system. https://doi.org/10.1016/j.neuron.2019.02.029

Massaly N, Morón JA, Al-Hasani R (2016) A trigger for opioid misuse: chronic pain and stress dysregulate the mesolimbic pathway and kappa opioid system. Front Neurosci 10:480. https://doi.org/10. 3389/fnins.2016.00480

Mika J, Jurga AM, Starnowska J, Wasylewski M, Rojewska E, Makuch W, Kwiatkowski K, Malek N, Przewlocka B (2015) Effects of chronic doxepin and amitriptyline administration in naïve mice and in neuropathic pain mice model. Neuroscience 294:38-50. https://doi.org/10.1016/j.neuroscience.2015.03.003

Mika J, Osikowicz M, Rojewska E, Korostynski M, Wawrzczak-Bargiela A, Przewlocki R, Przewlocka B (2009) Differential activation of spinal microglial and astroglial cells in a mouse model of peripheral neuropathic pain. Eur J Pharmacol 623:65-72. https://doi.org/10. 1016/j.ejphar.2009.09.030

Mika J, Zychowska M, Popiolek-Barczyk K, Rojewska E, Przewlocka B (2013) Importance of glial activation in neuropathic pain. Eur J Pharmacol 716:106-119. https://doi.org/10.1016/j.ejphar.2013.01. 072

Miura M, Saino-Saito S, Masuda M, Kobayashi K, Aosaki T (2007) Compartment-specific modulation of GABAergic synaptic transmission by mu-opioid receptor in the mouse striatum with green fluorescent protein-expressing dopamine islands. J Neurosci 27: 9721-9728. https://doi.org/10.1523/JNEUROSCI.2993-07.2007

Nahin RL (2015) Estimates of pain prevalence and severity in adults: United States, 2012. J Pain 16:769-780. https://doi.org/10.1016/j. jpain.2015.05.002

Narita M, Kishimoto Y, Ise Y, Yajima Y, Misawa K, Suzuki T (2005) Direct evidence for the involvement of the mesolimbic kappa-opioid system in the morphine-induced rewarding effect under an inflammatory pain-like state. Neuropsychopharmacology 30:111-118. https://doi.org/10.1038/sj.npp.1300527

Niikura K, Narita M, Butelman ER, Kreek MJ, Suzuki T (2010) Neuropathic and chronic pain stimuli downregulate central muopioid and dopaminergic transmission. Trends Pharmacol Sci 31: 299-305. https://doi.org/10.1016/j.tips.2010.04.003

Olive MF, Anton B, Micevych P, Evans CJ, Maidment NT (1997) Presynaptic versus postsynaptic localization of mu and delta opioid receptors in dorsal and ventral striatopallidal pathways. J Neurosci 17:7471-7479. https://doi.org/10.1523/JNEUROSCI.17-19-07471. 1997

Osikowicz M, Mika J, Makuch W, Przewlocka B (2008) Glutamate receptor ligands attenuate allodynia and hyperalgesia and potentiate morphine effects in a mouse model of neuropathic pain. Pain 139: 117-126. https://doi.org/10.1016/j.pain.2008.03.017

Oude Ophuis RJ, Boender AJ, van Rozen AJ, Adan RA (2014) Cannabinoid, melanocortin and opioid receptor expression on DRD1 and DRD2 subpopulations in rat striatum. Front Neuroanat 8:14. https://doi.org/10.3389/fnana.2014.00014

Ozaki S, Narita M, Narita M, Iino M, Sugita J, Matsumura Y, Suzuki T (2002) Suppression of the morphine-induced rewarding effect in the 
rat with neuropathic pain: implication of the reduction in mu-opioid receptor functions in the ventral tegmental area. J Neurochem 82: 1192-1198. https://doi.org/10.1046/j.1471-4159.2002.01071.x

Palmisano M, Caputi FF, Mercatelli D, Romualdi P, Candeletti S (2018) Dynorphinergic system alterations in the corticostriatal circuitry of neuropathic mice support its role in the negative affective component of pain. Genes Brain Behav:e12467. https://doi.org/10.1111/ gbb. 12467

Paxinos G, Franklin KBJ (2001) The mouse brain in stereotaxic coordinates, 2nd edn. Academic Press, CD-ROM edition

Perkinton MS, Sihra TS, Williams RJ (1999) Ca(2+)-permeable AMPA receptors induce phosphorylation of cAMP response elementbinding protein through a phosphatidylinositol 3-kinase-dependent stimulation of the mitogen-activated protein kinase signaling cascade in neurons. J Neurosci 19:5861-5874. https://doi.org/10. 1523/JNEUROSCI.19-14-05861.1999

Perreault ML, Hasbi A, Alijaniaram M, Fan T, Varghese G, Fletcher PJ, Seeman P, O'Dowd BF, George SR (2010) The dopamine D1-D2 receptor heteromer localizes in dynorphin/enkephalin neurons: increased high affinity state following amphetamine and in schizophrenia. J Biol Chem 285:36625-36634. https://doi.org/10.1074/ jbc.M110.159954

Reimer S, Sirinathsinghji DJ, Nikolorakis KE, Höllt V (1992) Differential dopaminergic regulation of proenkephalin and prodynorphin mRNAs in the basal ganglia of rats. Mol Brain Res 12:259-266. https://doi.org/10.1016/0169-328X(92)90092-P

Ren W, Centeno MV, Berger S, Wu Y, Na X, Liu X, Kondapalli J, Apkarian AV, Martina M, Surmeier DJ (2016) The indirect pathway of the nucleus accumbens shell amplifies neuropathic pain. Nat Neurosci 19:220-222. https://doi.org/10.1038/nn.4199

Rojewska E, Popiolek-Barczyk K, Jurga AM, Makuch W, Przewlocka B, Mika J (2014) Involvement of pro- and antinociceptive factors in minocycline analgesia in rat neuropathic pain model. J Neuroimmunol 277:57-66. https://doi.org/10.1016/j.jneuroim. 2014.09.020

Rojewska E, Wawrzczak-Bargiela A, Szucs E, Benyhe S, Starnowska J, Mika J, Przewlocki R, Przewlocka B (2018) Alterations in the activity of spinal and thalamic opioid systems in a mice neuropathic pain model. Neuroscience 390:293-302. https://doi.org/10.1016/j. neuroscience.2018.08.013

Saadé NE, Atweh SF, Bahuth NB, Jabbur SJ (1997) Augmentation of nociceptive reflexes and chronic deafferentation pain by chemical lesions of either dopaminergic terminals or midbrain dopaminergic neurons. Brain Res 751:1-12. https://doi.org/10.1016/S00068993(96)01164-X

Sagheddu C, Aroni S, De Felice M, Lecca S, Luchicchi A, Melis M, Muntoni AL, Romano R, Palazzo E, Guida F, Maione S, Pistis M (2015) Enhanced serotonin and mesolimbic dopamine transmissions in a rat model of neuropathic pain. Neuropharmacology 97:383393. https://doi.org/10.1016/j.neuropharm.2015.06.003

Schmidt BL, Tambeli CH, Levine JD, Gear RW (2002) mu/delta Cooperativity and opposing kappa-opioid effects in nucleus accumbens-mediated antinociception in the rat. Eur J Neurosci 15: 861-868. https://doi.org/10.1046/j.1460-9568.2002.01915.x

Scott DJ, Heitzeg MM, Koeppe RA, Stohler CS, Zubieta JK (2006) Variations in the human pain stress experience mediated by ventral and dorsal basal ganglia dopamine activity. J Neurosci 26:1078910795. https://doi.org/10.1523/JNEUROSCI.2577-06.2006

Sesack SR, Grace AA (2010) Cortico-basal ganglia reward network: microcircuitry. Neuropsychopharmacology 35:27-47. https://doi. org/10.1038/npp.2009.93

Short JL, Ledent C, Borrelli E, Drago J, Lawrence AJ (2006) Genetic interdependence of adenosine and dopamine receptors: evidence from receptor knockout mice. Neuroscience 139:661-670. https:// doi.org/10.1016/j.neuroscience.2005.12.052
Spanagel R, Herz A, Shippenberg TS (1992) Opposing tonically active endogenous opioid systems modulate the mesolimbic dopaminergic pathway. Proc Natl Acad Sci U S A 89:2046-2050. https://doi.org/ 10.1073/pnas.89.6.2046

Steiner H, Gerfen CR (1999) Enkephalin regulates acute D2 dopamine receptor antagonist-induced immediate-early gene expression in striatal neurons. Neuroscience 88:795-810. https://doi.org/10. 1016/S0306-4522(98)00241-3

Su C, D'amour J, Lee M, Lin HY, Manders T, Xu D, Eberle SE, Goffer Y, Zou AH, Rahman M, Ziff E, Froemke RC, Huang D, Wang J (2015) Persistent pain alters AMPA receptor subunit levels in the nucleus accumbens. Mol Brain 8:46. https://doi.org/10.1186/s13041-0150140-Z

Sung S, Vijiaratnam N, Chan DWC, Farrell M, Evans AH (2018) Pain sensitivity in Parkinson's disease: systematic review and meta-analysis. Parkinsonism Relat Disord 48:17-27. https://doi.org/10.1016/j. parkreldis.2017.12.031

Suzuki T, Kishimoto Y, Misawa M, Nagase H, Takeda F (1999) Role of the kappa-opioid system in the attenuation of the morphine-induced place preference under chronic pain. Life Sci 64:PL1-PL7. https:// doi.org/10.1016/S0024-3205(98)00537-2

Taylor AM, Becker S, Schweinhardt P, Cahill C (2016) Mesolimbic dopamine signaling in acute and chronic pain: implications for motivation, analgesia, and addiction. Pain 157:1194-1198. https://doi. org/10.1097/j.pain.0000000000000494

Taylor AM, Murphy NP, Evans CJ, Cahill CM (2014) Correlation between ventral striatal catecholamine content and nociceptive thresholds in neuropathic mice. J Pain 15:878-885. https://doi.org/10. 1016/j.jpain.2014.05.006

Tejeda HA, Shippenberg TS, Henriksson R (2012) The dynorphin/Kopioid receptor system and its role in psychiatric disorders. Cell. Mol. Life Sci 69:857-896. https://doi.org/10.1007/s00018-0110844-x

Tejeda HA, Wu J, Kornspun AR, Pignatelli M, Kashtelyan V, Krashes MJ, Lowell BB, Carlezon WA Jr, Bonci A (2017) Pathway- and cellspecific kappa-opioid receptor modulation of excitation-inhibition balance differentially gates D1 and D2 accumbens neuron activity. Neuron 93:147-163. https://doi.org/10.1016/j.neuron.2016.12.005

Tracey I, Mantyh PW (2007) The cerebral signature for pain perception and its modulation. Neuron 55:377-391. https://doi.org/10.1016/j. neuron.2007.07.012

Turk DC (2001) Combining somatic and psychosocial treatment for chronic pain patients: perhaps $1+1$ does $=3$. Clin J Pain 17:281283

Wood PB (2006) Mesolimbic dopaminergic mechanisms and pain control. Pain 120:230-234. https://doi.org/10.1016/j.pain.2005.12.014

Wood PB, Schweinhardt P, Jaeger E, Dagher A, Hakyemez H, Rabiner EA, Bushnell MC, Chizh BA (2007) Fibromyalgia patients show an abnormal dopamine response to pain. Eur J Neurosci 25:35763582. https://doi.org/10.1111/j.1460-9568.2007.05623.x

Wu Y, Na X, Zang Y, Cui Y, Xin W, Pang R, Zhou L, Wei X, Li Y, Liu X (2014) Upregulation of tumor necrosis factor-alpha in nucleus accumbens attenuates morphine-induced rewarding in a neuropathic pain model. Biochem Biophys Res Commun 449:502-507. https:// doi.org/10.1016/j.bbrc.2014.05.025

Yaksh TL, Wallace MS (2011) Opioids, analgesia, and pain management. In: Brunton LL, Chabner BA, Knollmann BC (eds) Goodman \& Gilman's the pharmacological basis of therapeutics, 12th edn. McGraw-Hill Professional Publishing, pp 481-525

Yoshikawa K, Williams C, Sabol SL (1984) Rat brain preproenkephalin mRNA. cDNA cloning, primary structure, and distribution in the central nervous system. J Biol Chem 259:14301-14308 http:// www.jbc.org/content/259/22/14301.long

Young WS 3rd, Bonner TI, Brann MR (1986) Mesencephalic dopamine neurons regulate the expression of neuropeptide mRNAs in the rat 
forebrain. Proc Natl Acad Sci U S A 83:9827-9831. https://doi.org/ 10.1073/pnas.83.24.9827

Zambito Marsala S, Tinazzi M, Vitaliani R, Recchia S, Fabris F, Marchini C, Fiaschi A, Moretto G, Giometto B, Macerollo A, Defazio G (2011) Spontaneous pain, pain threshold, and pain tolerance in Parkinson's disease. J Neurol 258:627-633. https://doi.org/10. 1007/s00415-010-5812-0

Zhou L, Furuta T, Kaneko T (2003) Chemical organization of projection neurons in the rat accumbens nucleus and olfactory tubercle. Neuroscience 120:783-798. https://doi.org/10.1016/S03064522(03)00326-9

Zimmermann M (1983) Ethical guidelines for investigations of experimental pain in conscious animals. Pain 16:109-110. https://doi.org/ 10.1016/0304-3959(83)90201-4

Ziolkowska B, Gieryk A, Wawrzczak-Bargiela A, Krowka T, Kaminska D, Korkosz A, Bienkowski P, Przewlocki R (2008) alpha-Synuclein expression in the brain and blood during abstinence from chronic alcohol drinking in mice. Neuropharmacology 54:1239-1246. https://doi.org/10.1016/j.neuropharm.2008.04.001
Zubieta JK, Smith YR, Bueller JA, Xu Y, Kilbourn MR, Jewett DM, Meyer CR, Koeppe RA, Stohler CS (2001) Regional mu opioid receptor regulation of sensory and affective dimensions of pain. Science 293:311-315. https://doi.org/10.1126/science.1060952

Zubieta JK, Smith YR, Bueller JA, Xu Y, Kilbourn MR, Jewett DM, Meyer CR, Koeppe RA, Stohler CS (2002) mu-opioid receptor-mediated antinociceptive responses differ in men and women. J Neurosci 22:5100-5107. https://doi.org/10.1523/JNEUROSCI.2212-05100.2002

Zurawski G, Benedik M, Kamb BJ, Abrams JS, Zurawski SM, Lee FD (1986) Activation of mouse T-helper cells induces abundant preproenkephalin mRNA synthesis. Science 232:772-775. https:// doi.org/10.1126/science.2938259

Publisher's Note Springer Nature remains neutral with regard to jurisdictional claims in published maps and institutional affiliations. 